Article

\title{
Lycopene Inhibits Reactive Oxygen Species-Mediated NF-KB Signaling and Induces Apoptosis in Pancreatic Cancer Cells
}

\author{
Yoonseon Jeong, Joo Weon Lim and Hyeyoung Kim * \\ Department of Food and Nutrition, Brain Korea 21 PLUS Project, College of Human Ecology, Yonsei University, \\ Seoul 03722, Korea; j_yoonseon@naver.com (Y.J.); jwlim11@yonsei.ac.kr (J.W.L.) \\ * Correspondence: kim626@yonsei.ac.kr; Tel.: +82-2-2123-3125; Fax: +82-2-364-5781
}

Received: 20 February 2019; Accepted: 29 March 2019; Published: 1 April 2019

check for

updates

\begin{abstract}
Generation of excess quantities of reactive oxygen species (ROS) caused by mitochondrial dysfunction facilitates rapid growth of pancreatic cancer cells. Elevated ROS levels in cancer cells cause an anti-apoptotic effect by activating survival signaling pathways, such as NF- $\mathrm{kB}$ and its target gene expression. Lycopene, a carotenoid found in tomatoes and a potent antioxidant, displays a protective effect against pancreatic cancer. The present study was designed to determine if lycopene induces apoptosis of pancreatic cancer PANC-1 cells by decreasing intracellular and mitochondrial ROS levels, and consequently suppressing NF- $\mathrm{kB}$ activation and expression of NF- $\mathrm{kB}$ target genes including cIAP1, cIAP2, and survivin. The results show that the lycopene decreased intracellular and mitochondrial ROS levels, mitochondrial function (determined by the mitochondrial membrane potential and oxygen consumption rate), NF- $\mathrm{KB}$ activity, and expression of NF- $\mathrm{kB}$-dependent survival genes in PANC-1 cells. Lycopene reduced cell viability with increases in active caspase-3 and the Bax to Bcl-2 ratio in PANC-1 cells. These findings suggest that supplementation of lycopene could potentially reduce the incidence of pancreatic cancer.
\end{abstract}

Keywords: apoptosis; NF-kB; lycopene; pancreatic cancer cells; reactive oxygen species

\section{Introduction}

Pancreatic cancer is one of the leading causes of cancer deaths in the western world [1,2]. The likelihood of surviving this disease is extremely low worldwide as indicated by the 5-year survival rate of about $6 \%$ (ranges from $2 \%$ to $9 \%$ ) [3]. In Korea, the 5-year survival rate of the pancreatic cancer was $8.8 \%$ in 2012 [4]. The ability of cells to evade apoptosis, a hallmark of human cancers, could be the reason for the strong resistance of pancreatic cancer to currently available treatments [5].

The currently available drugs in the market used for the treatment of pancreatic cancer are gemcitabine $\left(2^{\prime}, 2^{\prime}\right.$-difluorodeoxycytidine, GEM) and 5-fluorouracil (5-FU) [6,7]. These drugs exert their anticancer effects through the inhibition of DNA synthesis. In a single comparative study in patients with advanced pancreatic cancer, GEM was more effective than 5-FU with respect to survival duration and general clinical status [8]. Lee [9] recently reported that combination chemotherapy with 5-FU plus GEM yielded better survival rates than GEM monotherapy in pancreatic cancer patients. Like most anticancer agents, GEM and 5-FU induce ROS [10], which serve as additional anticancer mechanism. ROS induce various tissue damage [11]. Therefore, cells have to protect against cell damage by developing highly regulated antioxidant defense system. Ju et al. [12] reported that GEM-induced ROS stimulate the transcription of cytoprotective antioxidant genes, especially glutathione-generating enzymes. Increased antioxidant defense in GEM-treated cells make cancer cells resistant to GEM. Thus, the combination of an anticancer agent with antioxidant supplement has been suggested [13]. 
However, combination of 5-FU and antioxidant decreased the anticancer effect of 5-FU [14]. Therefore, prevention of pancreatic cancer by nutrient supplements or consumption of foods containing bioactive components becomes more important than cancer treatment by anticancer agents.

Although reactive oxygen species (ROS) are important regulators of normal cellular processes, uncontrolled generation of ROS contributes to the development of cancers. Owing to the accelerated metabolism, cancer cells have higher ROS levels than normal cells [15]. ROS facilitate cancer development by causing direct oxidative damage to DNA, and inducing lipid peroxidation or oxidizing proteins $[16,17]$. The major source of ROS production inside cells is the mitochondrial electron transport chain which generates electrons that can react with molecular oxygen [18].

The most well known metabolic abnormality in cancer cells is mitochondrial dysfunction, which renders the cells adapt glycolysis to generate adenosine triphosphate (ATP) even in the presence of oxygen, namely Warburg effect $[19,20]$. Warburg found that unlike normal cells, cancer cells tend to ferment glucose into lactate even in the presence of sufficient oxygen to support mitochondrial oxidative phosphorylation. Since energy requirements for cell proliferation are high, cancer cells complete catabolism of glucose using mitochondrial oxidative phosphorylation to maximize ATP production using Warburg effect [21]. Key enzymes implicated in the control of glucose metabolism and mitochondrial respiration are relatively highly expressed in cancers. Moreover, the expression levels of these key enzymes correlate with poor patient outcomes [22]. A large amount of evidence suggests that cancer cells exhibit increased intrinsic ROS stress, which enhances tumor metabolic adaptation, proliferation, survival and angiogenesis. Increased oxidative stress in cancer cells may be partly caused by mitochondrial dysfunction [23-25].

Elevated levels of ROS have anti-apoptotic effects in cancer cells that result from activation of redox-sensitive transcription factors such as nuclear factor $\mathrm{k}$-light-chain-enhancer of activated $\mathrm{B}$ cells (NF- $\mathrm{KB}$ ). NF- $\mathrm{KB}$ activation leads to stimulation of cellular proliferation, cell migration and invasion, all of which contribute to carcinogenesis $[26,27]$. NF- $\mathrm{kB}$, one of the key regulatory components in the anti-apoptotic signaling pathway, is a typical example of a transcription factor whose activity is subject to redox modulation $[28,29]$. In normal cells, NF- $k B$ is localized in the cytosol in an inactive

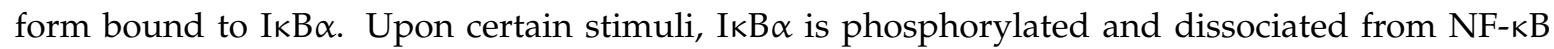
for degradation. However, in cancer cells, NF- $\mathrm{kB}$ is maintained in an active form that promotes expression of pro-survival genes such as inhibitors of apoptosis (IAPs), which results in uncontrolled cell growth [30]. IAPs such as cIAP1, cIAP2, and survivin are involved in cell proliferation and survival, and are regulated at the gene level by activation of NF- $\mathrm{KB}$ [31]. Because NF- $\mathrm{kB}$ plays a pivotal role in mediating cell survival, blocking its NF- $\mathrm{KB}$ activity can alter the survival/death balance of tumor cells. Thus, targeting NF- $\mathrm{kB}$ might be an effective approach for developing treatments that combat human cancers.

To date, eight IAPs, which are intrinsic cellular inhibitors of apoptosis [32], have been identified. These include NAIP (BIRC1), c-IAP1 (BIRC2), c-IAP2 (BIRC3), X-linked IAP (XIAP, BIRC4), survivin (BIRC5), apollon (BRUCE, BIRC6), livin/ML-IAP (BIRC7) and IAP-like protein 2 (BIRC8). Among IAPs, cIAP1, cIAP2, and survivin promote the degradation of active caspase or block interactions between caspases and their substrates. A decrease in IAP levels induces apoptosis in pancreatic cancer cells $[33,34]$. Taken together, ROS induce NF-kB-mediated expression of IAPs in cancer cells. Therefore, reducing the generation and scavenging ROS by exogenous compounds in cancer cells should promote cancer cell death by decreasing IAPs.

Lycopene, an active component in tomatoes and other red vegetables, is a potent antioxidant and displays anticancer activities against various types of cancer such as prostate, pancreatic, breast and gastric cancer [35-37]. Epidemiologic studies have shown that a high intake of lycopene is associated with a reduced risk of pancreatic cancer [38-41]. In addition, genetic variations in the capacity to defend against oxidative stress and to repair oxidative DNA damage affect the risk of pancreatic cancer. However, some of these genetic predispositions can be alleviated by dietary antioxidants including lycopene [42]. Lycopene suppressed ROS-mediated cancer cell growth [43] and NF-kB 
nuclear binding in macrophages and SK-Hep-1 cells from a human hepatoma [44,45]. These studies suggest that lycopene has the potential beneficial effects in the prevention and treatment of pancreatic cancer through its inhibitory effect on cell proliferation promoted by ROS.

In the present study, we assessed the anti-cancer effect of lycopene on pancreatic cancer PANC-1 cells by determining its impact on cell viability, apoptotic indices (levels of active caspase- 3 and ratio of Bax to Bcl-2), intracellular and mitochondrial ROS levels, and mitochondrial function (mitochondrial membrane potential (MMP) and oxygen consumption rate (OCR) as an index for mitochondrial oxidative phosphorylation). Activation of NF-kB, determined by measuring the level of IkB $\alpha$ phosphorylation and the NF- $\mathrm{kB}-\mathrm{DNA}$ binding activity, and the expression of NF- $\mathrm{kB}$ target genes cIAP1, cIAP2 and survivin were also evaluated.

\section{Materials and Methods}

\subsection{Cell Line and Culture Condition}

Human pancreatic cancer cells (PANC-1) were obtained from American Type Culture Collection (Rockville, MD, USA) and maintained in Dulbecco's Modified Eagle's Medium (DMEM) medium (GIBCO, Grand Island, NY, USA) containing $4500 \mathrm{mg}$ glucose/L and supplemented with 10\% heat-inactivated fetal bovine serum (GIBCO) and antibiotic-antimycotic solution (100 U/mL penicillin and $100 \mu \mathrm{g} / \mathrm{mL}$ streptomycin). The cells were incubated at $37^{\circ} \mathrm{C}$ in a humidified atmosphere of $5 \%$ $\mathrm{CO}_{2}$ and $95 \%$ air.

\subsection{Experimental Protocol}

PANC-1 cells $\left(1-5 \times 10^{4} / \mathrm{mL}\right)$ were treated with a solution of lycopene (L9879, Sigma-Aldrich, St. Louis, MO, USA) in tetrahydrofuran (THF) to produce final lycopene concentrations of 0.25 or $0.5 \mu \mathrm{M}$. The mixtures were then incubated for $24 \mathrm{~h}$ to determine cell viability, the levels Bcl-2 and Bax, intracellular and mitochondrial ROS levels, OCR, DNA binding activity of NF-kB and mRNA and protein expression of IkB $\alpha$, cIAP1, cIAP2, and survivin. Controls for the experiments were PANC-1 cells incubated with THF (less than $0.3 \%$ ) alone.

\subsection{Determination of Cell Viability}

The cells were seeded $\left(1 \times 10^{4} / \mathrm{mL}\right)$ in a 96-well plate and then cultured overnight. The cells were then treated with lycopene for $24 \mathrm{~h}$. PANC-1 cells were incubated for $3 \mathrm{~h}$ with MTT (3-(4,5-dimethylthiazol-2-yl)-2,5-diphenyltetrazolium bromide; Sigma-Aldrich, St. Louis, MO, USA) in phosphate-buffered saline (PBS). The cells were lysed by mixing with 2-propanol in $0.1 \% \mathrm{HCl}$ for $20 \mathrm{~min}$ using a shaker. The absorbances of the resulting mixtures were measured spectrophotometrically using a microplate reader (Molecular Devices, Sunnyvale, CA, USA).

\subsection{Measurement of Intracellular Reactive Oxygen Species (ROS) Levels}

The cells $\left(5 \times 10^{4} / \mathrm{mL}\right)$ were treated with lycopene for $24 \mathrm{~h}$. For measurements of intracellular ROS, the cells were treated with $10 \mu \mathrm{g} / \mathrm{mL}$ of dichlorofluorescein diacetate (DCF-DA; Sigma-Aldrich) and incubated in $5 \% \mathrm{CO}_{2} / 95 \%$ air at $37^{\circ} \mathrm{C}$ for $30 \mathrm{~min}$. The intensities of DCF fluorescence at $535 \mathrm{~nm}$ (excitation at $495 \mathrm{~nm}$ ) were measured with a Victor 5 multi-label counter (PerkinElmer Life and Analytical Sciences, Boston, MA, USA). The intracellular ROS levels were normalized to cell numbers.

\subsection{Measurement of Mitochondrial ROS Levels}

The cells $\left(5 \times 10^{4} / \mathrm{mL}\right)$ were treated with lycopene for $24 \mathrm{~h}$. To assess mitochondrial ROS levels, the cells were treated with $10 \mu \mathrm{M}$ MitoSOX (Life technologies, Grand Island, NY, USA) for $30 \mathrm{~min}$, before being washed and scraped into PBS. The intensity of MitoSOX fluorescence at $585 \mathrm{~nm}$ (excitation at $524 \mathrm{~nm}$ ) was measured with a Victor 5 multi-label counter (PerkinElmer Life and Analytical Sciences). 
The mitochondrial ROS levels were normalized to cell numbers and thus, ROS levels were assessed based on equal cell numbers.

\subsection{Measurement of Oxygen Consumption Rate (OCR)}

OCR was assessed in real-time with a Seahorse XF96 Extracellular Flux Analyzer (Seahorse Bioscience, Billerica, MA, USA), which allows to measure OCR changes after sequential addition of modulators of respiration that target components of the electron transport chain in mitochondria. Cells $\left(1 \times 10^{4}\right.$ cells/well $/ 200 \mu \mathrm{L}$ of DMEM) were plated in a XF 96 cell culture microplate (Seahorse Bioscience Inc., Billerica, MA, USA). Cells were washed with base media once, immersed in $175 \mu \mathrm{L}$ base media, and incubated in the absence of $\mathrm{CO}_{2}$ for $20 \mathrm{~min}$. After baseline measurements, respiration was measured after sequentially adding $25 \mu \mathrm{L}$ of oligomycin (inhibitor of ATP synthase, $1 \mu \mathrm{g} / \mathrm{mL}$ ), carbonyl cyanide-4 (trifluoromethoxy) phenylhydrazone (FCCP) (a protonophore and uncoupler of mitochondrial oxidative phosphorylation, $0.5 \mu \mathrm{M}$ ), and a combination of rotenone (mitochondrial complex I inhibitor, $1 \mu \mathrm{M}$ ) and antimycin A (mitochondrial complex III inhibitor, $1 \mu \mathrm{M}$ ) for OCR measurement using the XF Cell Mito Stress Test Kit (Cat. No. 103015-100, Seahorse Bioscience Inc., Billerica, MA, USA). OCR values were normalized for the protein content of each sample and expressed as the unit of pmoles/min. Basal OCR was expressed as percentage of the untreated cells (None). Basal OCR for "None" was set at 100.

\subsection{Measurement of Mitochondrial Membrane Potential (MMP)}

To determine changes in MMP, the cells were cultured on glass coverslips coated with Poly-L-lysine, pretreated with lycopene for $24 \mathrm{~h}$. The cells were then incubated with 5,5',6,6'-tetrachloro- $1,1^{\prime}, 3,3^{\prime}-$ tetraethyl benzimidazolyl carbocyanine iodide (JC-1) reagent (1:100; 10009908, Cayman Chemical Company, Ann Arbor, MI, USA) for $20 \mathrm{~min}$. After removal of the media, the cells were dried for $15 \mathrm{~min}$ at room temperature, washed twice with PBS for $5 \mathrm{~min}$, and mounted with mounting solution (M-7534, Sigma Aldrich, St. Louis, MO, USA). Fluorescence of JC-1 in the cells was determined (red; excitation at $590 \mathrm{~nm}$ and emission at $610 \mathrm{~nm}$, green; excitation at $485 \mathrm{~nm}$ and emission at 535 $\mathrm{nm}$ ) using a laser-scanning confocal microscope (LSM 880, Carl Zeiss Inc., Oberkochen, Germany). The fluorescence images were expressed as the percentage ratio of red and green intensities using NIH Image J 5.0 software (National Institutes of Health, Bethesda, MD, USA).

\subsection{Real-Time Polymerase Chain Reaction (PCR) Analysis for cIAP1, cIAP2, and Survivin}

The cells $\left(5 \times 10^{4} / \mathrm{mL}\right)$ were treated with lycopene for $24 \mathrm{~h}$. Total RNA was isolated by using TRI reagent (Molecular Research Center, Inc., Cincinnati, OH, USA). Total RNA was converted into cDNA by using reverse transcription with a random hexamer and MuLV reverse transcriptase (Promega, Madison, WI, USA) and by heating at $23^{\circ} \mathrm{C}$ for $10 \mathrm{~min}, 37^{\circ} \mathrm{C}$ for $60 \mathrm{~min}$ and $95^{\circ} \mathrm{C}$ for 5 min. The cDNA was used for real-time PCR with specific primers for cIAP1, cIAP2, survivin, and $\beta$-actin. The sequences of the cIAP1 primers used to produce the desired $160 \mathrm{bp}$ PCR products are 5'-AGCTGTTGTCAACTTCAGATACCACT-3' (forward primer) and 5'-TGTTTCACCAGGTCTCTATT AAAGCC- $3^{\prime}$ (reverse primer). For cIAP2 cDNA production, the $160 \mathrm{bp}$ PCR product was obtained by using the forward primer $5^{\prime}$-TCCTGGATAGTCTACTAACTGCC $-3^{\prime}$ and reverse primer $5^{\prime}$-GCTTCTT GCAGAGAGTTTCTGAA- $3^{\prime}$. Sequences of survivin primers were $5^{\prime}$-ATGGGTGCCCCGACGTT- $3^{\prime}$ (forward primer) and $5^{\prime}$-TCAATCCATGGCAGCCAG- $3^{\prime}$ (reverse primer) to produce the desired $594 \mathrm{bp}$ PCR product. For $\beta$-actin cDNA production, the $349 \mathrm{bp}$ PCR product was obtained by using the forward primer $5^{\prime}$-ACCAACTGGGACGACATGGAG-3 ${ }^{\prime}$ and reverse primer $5^{\prime}$-GTGAGGATCTTC ATGAGGTAGTC- $3^{\prime}$. For PCR amplification, the cDNA was amplified by 42 repeat denaturation cycles at $95{ }^{\circ} \mathrm{C}$ for $30 \mathrm{~s}$, annealing at $58{ }^{\circ} \mathrm{C}$ for $30 \mathrm{~s}$, and extension at $72{ }^{\circ} \mathrm{C}$ for $45 \mathrm{~s}$. During the first cycle, the $95^{\circ} \mathrm{C}$ step was extended to $3 \mathrm{~min}$. The $\beta$-actin gene was amplified in the same reaction to serve as the reference gene. 


\subsection{Preparation of Cell Extracts}

The cells $\left(5 \times 10^{4} / \mathrm{mL}\right)$ were treated with lycopene $(0.25$ and $0.5 \mu \mathrm{M})$ for $24 \mathrm{~h}$. Cells were harvested by scraping with PBS, and pelleted by centrifugation at $5000 \times \mathrm{g}$ for $15 \mathrm{~min}$. The cell pellets were re-suspended with lysis buffer containing $10 \mathrm{mM}$ Tris $\mathrm{pH} 7.4,1 \% \mathrm{NP}-40$ and a commercial protease inhibitor complex (Complete; Roche, Mannheim, Germany), and the cells were lysed by drawing the suspension through a 1-mL syringe using several rapid strokes. The mixture was then incubated on ice for $30 \mathrm{~min}$ and centrifuged at $13,000 \times \mathrm{g}$ for $15 \mathrm{~min}$, giving supernatants that were collected and used as whole-cell extracts. To prepare the nuclear extracts, the cell pellets were re-suspended with $30 \mu \mathrm{L}$ of hypotonic buffer, containing $10 \mathrm{mM}$ 4-(2-hydroxyethyl)-1-piperazineethanesulfonic acid (HEPES) pH 7.9, $1.5 \mathrm{mM} \mathrm{MgCl}_{2}, 10 \mathrm{~m} \mathrm{KCl}, 0.5 \mathrm{mM}$ DTT, $0.5 \mathrm{mM} \mathrm{PMSF}, 0.2 \% \mathrm{NP}-40$, and then placed on ice for $20 \mathrm{~min}$. The extracts were centrifuged at $13,000 \times \mathrm{g}$ for $20 \mathrm{~min}$ at $4{ }^{\circ} \mathrm{C}$. The pellets were re-suspended in $30 \mu \mathrm{L}$ of extraction buffer, containing $20 \mathrm{mM}$ HEPES pH 7.9, $420 \mathrm{mM} \mathrm{NaCl}, 0.2 \mathrm{mM}$ ethylenediaminetetraacetic acid (EDTA), $1.5 \mathrm{mM} \mathrm{MgCl}_{2}, 25 \%$ glycerol, $0.5 \mathrm{mM}$ DTT, $0.5 \mathrm{mM}$ PMSF, and placed on ice for $20 \mathrm{~min}$. The extracts were subsequently centrifuged at $13,000 \times g$ for $20 \mathrm{~min}$ at $4{ }^{\circ} \mathrm{C}$, and the supernatants were used as the nuclear extracts. Protein concentrations were determined by using Bradford assay (Bio-Rad Laboratories, Hercules, CA, USA).

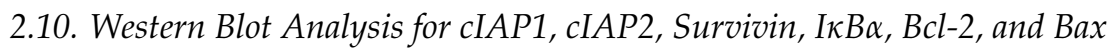

The cells $\left(5 \times 10^{4} / \mathrm{mL}\right)$ were treated with lycopene $(0.25$ and $0.5 \mu \mathrm{M})$ for $24 \mathrm{~h}$. Aliquots from whole cell extracts were loaded onto $8 \%-12 \%$ sodium dodecyl sulfate (SDS) polyacrylamide gel (20-40 $\mu \mathrm{g}$ protein/lane) and subjected to electrophoresis under reducing conditions. The separated proteins were transferred to nitrocellulose membranes (Amersham, Inc., Arlington Heights, IL, USA) by electroblotting. Successful transfer of the proteins was verified using reversible staining with Ponceau S. The membranes were blocked using 3\% non-fat dry milk in TBS-T (Tris-buffered saline and $0.2 \%$ Tween 20). The proteins were detected using antibodies for Bax (sc-526, Santa Cruz Biotechnology, CA, USA), Bcl-2 (sc-492, Santa Cruz Biotechnology, CA, USA), IкB $\alpha$ (sc-371, Santa Cruz Biotechnology, CA, USA), p-IкB $\alpha$ (\#2859, Cell signaling Technology, Danvers, MA, USA), cIAP1(\#AF8181, R\&D systems), cIAP2(\#MAB817, R\&D systems), survivin (sc-10811, Santa Cruz Biotechnology, CA, USA) and actin (sc-1615, Santa Cruz Biotechnology) in TBS-T solution containing 3\% dry milk, and incubated overnight at $4{ }^{\circ} \mathrm{C}$. After washing with TBS-T, the primary antibodies were detected using horseradish peroxidase-conjugated secondary antibodies (anti-mouse, anti-rabbit, anti-goat), and using the enhanced chemiluminescence detection system (Santa Cruz Biotechnology). Actin served as a loading control. The ratio of Bax/Bcl-2 was determined from the protein-band densities of Bax and Bcl-2. The values are expressed as mean \pm standard error (S.E.) of four different experiments.

\subsection{Electrophoretic Mobility Shift Assay (EMSA)}

The cells $\left(5 \times 10^{4} / \mathrm{mL}\right)$ were treated with lycopene for $24 \mathrm{~h}$. Nuclear extracts $(0.3 \mu \mathrm{g})$ of the cells were incubated with the ${ }^{32} \mathrm{P}$-labeled double-stranded oligonucleotide $5^{\prime}$-GGGCCAAGAATCTTAGC AGTTTCGGG-3 in buffer containing 12\% glycerol, 12 mM Hepes (pH 7.9), 1 mM EDTA, 1 mM DTT, $25 \mathrm{mM} \mathrm{KCl}, 5 \mathrm{mM} \mathrm{MgCl}$, and $0.04 \mu \mathrm{g} / \mathrm{mL}$ poly[d(I-C)] at room temperature for $30 \mathrm{~min}$. The extracts were then subjected to electrophoretic separation at room temperature on a non-denaturing $5 \%$ acrylamide gel at $30 \mathrm{~mA}$ using $0.5 \times$ Tris borate/EDTA buffer. The gels were dried at $80^{\circ} \mathrm{C}$ for $1 \mathrm{~h}$ and exposed to radiography film for $24 \mathrm{~h}$ at $-70^{\circ} \mathrm{C}$ with intensifying screens.

\subsection{Statistical Analysis}

One-way analysis of variance (ANOVA), followed by Newman-Keul's post hoc test, was used for statistical analysis. All data are reported as the mean \pm S.E. of four different experiments. A $p$-value of 0.05 or less was considered to be statistically significant. 


\section{Results}

\subsection{Lycopene Induces Apoptosis in PANC-1 Cells}

To determine the effect of lycopene on proliferation of PANC-1 cells, cell viability was measured using the MTT assay. As shown in Figure 1A, the viability of cells treated with lycopene decreased in a dose-dependent manner compared to that of untreated cells. To examine whether lycopene-induced decrease in cell viability is a consequence of an apoptotic effect, caspase-3 activation was determined by cleavage of pro-caspase-3 in lycopene-treated cells. Figure $1 \mathrm{~B}$ showed that the level of the cleaved active form of caspase-3 increased in dose-dependent response to lycopene. Lycopene also promoted an increase in the level of pro-apoptotic Bax and a decrease in the level of anti-apoptotic Bcl-2 (Figure 1C), resulting in a dose-dependent increase in the Bax/Bcl-2 ratio.

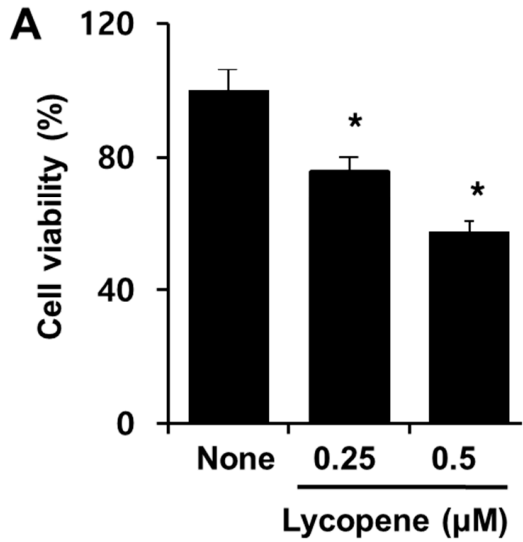

B

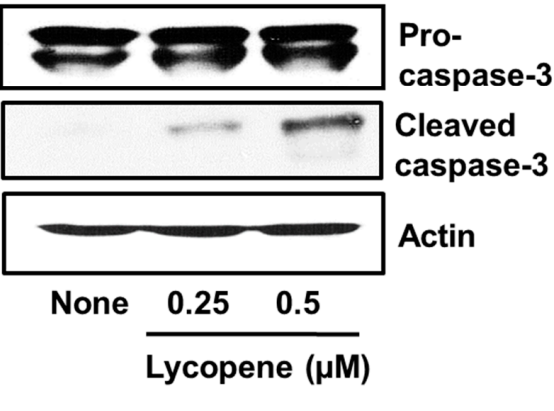

C
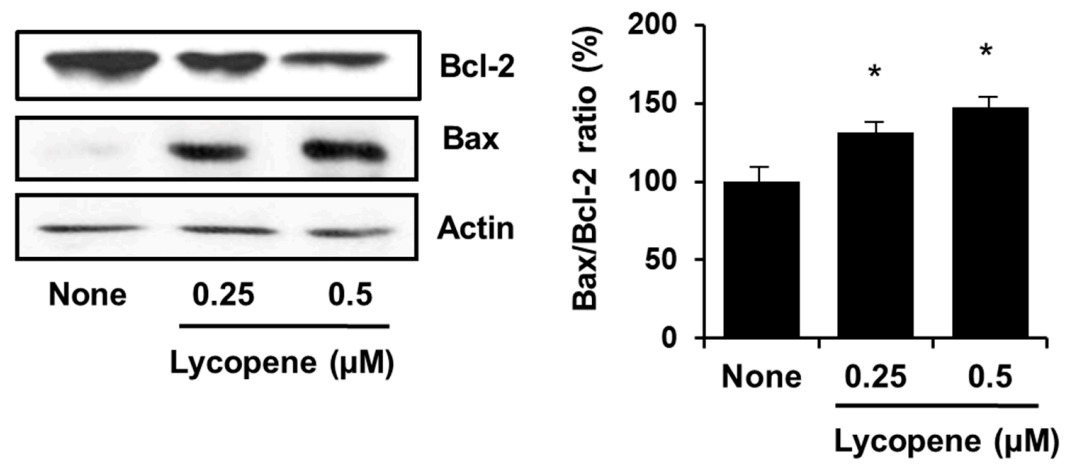

Figure 1. Lycopene decreased cell viability and increased caspase- 3 activation and the Bax/Bcl-2 ratio in PANC-1 cells. Cells were treated with the indicated concentrations of lycopene for $24 \mathrm{~h}$. (A) Cell viability was measured using the 3-(4,5-dimethylthiazol-2-yl)-2,5-diphenyltetrazolium bromide (MTT) assay. * $p<0.05$ vs. "None". None corresponds to the untreated cells; " 0.25 " and " 0.5 " correspond to the cells treated with 0.25 and $0.5 \mu \mathrm{M}$ lycopene, respectively. (B) Caspase- 3 activation was determined by the measuring the levels of pro-caspase- 3 and cleaved caspase- 3 in the cells. Designations of the columns are the same as in (A). (C) Levels of Bcl-2 and Bax in whole cell extracts were determined by using Western blot analysis. Designations of the columns are the same as in (A). The ratio of Bax/Bcl-2 was determined from the Bax and Bcl-2 protein band densities. * $p<0.05$ vs. "None". Designations of the columns are the same as in (A). The Bax/Bcl-2 ratio for "None" was set at 100.

\subsection{Lycopene Decreases Intracellular and Mitochondrial ROS Levels and OCR in PANC-1 Cells}

As shown in Figure 2A,B, lycopene caused decreases in intracellular and mitochondrial ROS levels in PANC-1 cells. To investigate whether mitochondrial function is affected in lycopene-induced 
apoptosis, OCR changes were measured. Real-time analysis of OCR changes was assessed by perturbing cells with modulators of respiration (oligomycin, FCCP, rotenone and antimycin A). Oligomycin is an inhibitor of ATP synthase (complex V). After injection of oligomycin, OCR decreased, which correlates to reduced mitochondrial respiration associated with cellular ATP production. FCCP is an uncoupling agent. After injection of FCCP, OCR is stimulated which can be used to calculate spare respiratory capacity. After a third injection of a mix of rotenone, a complex I inhibitor, and antimycin A, a complex Ill inhibitor, mitochondrial respiration decreased which enables the calculation of non-mitochondrial respiration. Therefore, monitoring the changes of OCR after injection of each modulator might be a good determination of mitochondrial function. All groups responded to these modulators in a similar way even though the OCR levels were different among groups (Figure 2C). Lycopene-treated cells showed relatively low OCR changes in response to the modulators compared to untreated cells. Figure 2D showed that basal OCR decreased in cells treated with lycopene, indicating that lycopene causes a reduction in mitochondrial function of PANC-1 cells. These results demonstrate that lycopene inhibits mitochondrial function and reduces mitochondrial and intracellular ROS levels in PANC-1 cells.
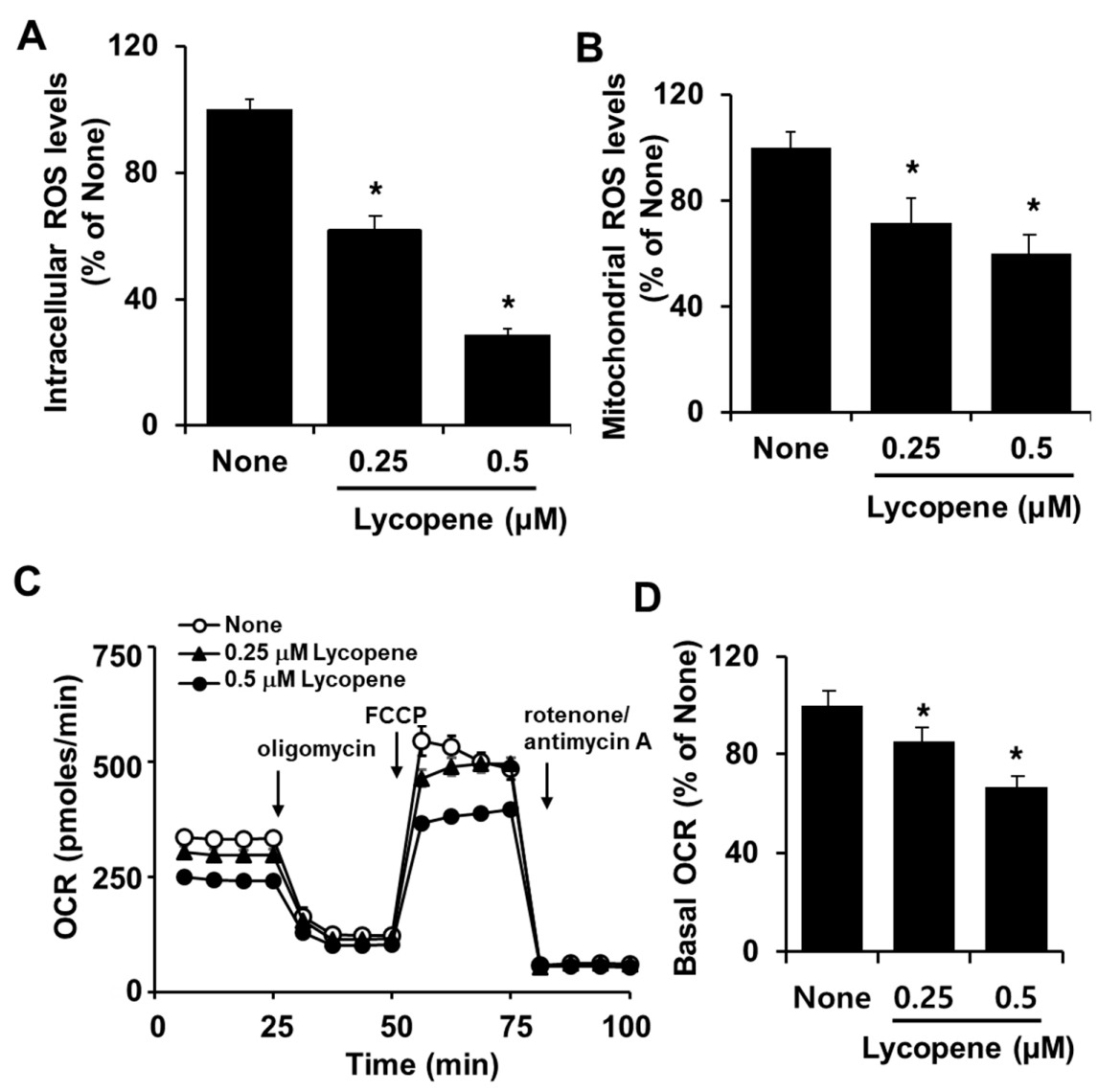

Figure 2. Lycopene decreased intracellular and mitochondrial reactive oxygen species (ROS) levels and oxygen consumption rate (OCR) in PANC-1 cells. Cells were treated with the indicated concentrations of lycopene for $24 \mathrm{~h}$. (A,B) Intracellular and mitochondrial ROS levels were determined using dichlorofluorescein diacetate (DCF-DA) and MitoSoX, respectively. ${ }^{*} p<0.05$ vs. the corresponding "None". "None" corresponds to the untreated cells; " 0.25 " and " 0.5 " correspond to the cells treated with 0.25 and $0.5 \mu \mathrm{M}$ lycopene, respectively. (C) The Seahorse XF96 analyzer was employed to assess OCR. Real-time analysis of OCR was assessed by perturbing cells with metabolic modulators (oligomycin, FCCP, rotenone and antimycin A). (D) Basal OCR was expressed as \% of None. OCR for "None" was set at $100 .{ }^{*} p<0.05$. Designations of the columns are the same as in (A). 


\subsection{Lycopene Decreases MMP in PANC-1 Cells}

JC-1 color change was used to determine MMP function. At lower energy state of mitochondria, JC-1 fluorescence is shown mainly as the green monomers, while higher MMP results in greater degrees of red JC-1 aggregates. We examined the ratio of aggregate and monomer fluorescence intensities in our confocal system by calibrating JC-1 fluorescence in PANC-1 cells. As shown in Figure 3, red and green fluorescence were found in untreated cells ("None"). Lycopene-treated cells showed prominent green fluorescence ("Lycopene") as compared to "None". JC-1 fluorescent color changed from red to green along with lycopene treatment, suggesting that lycopene induces MMP decline.

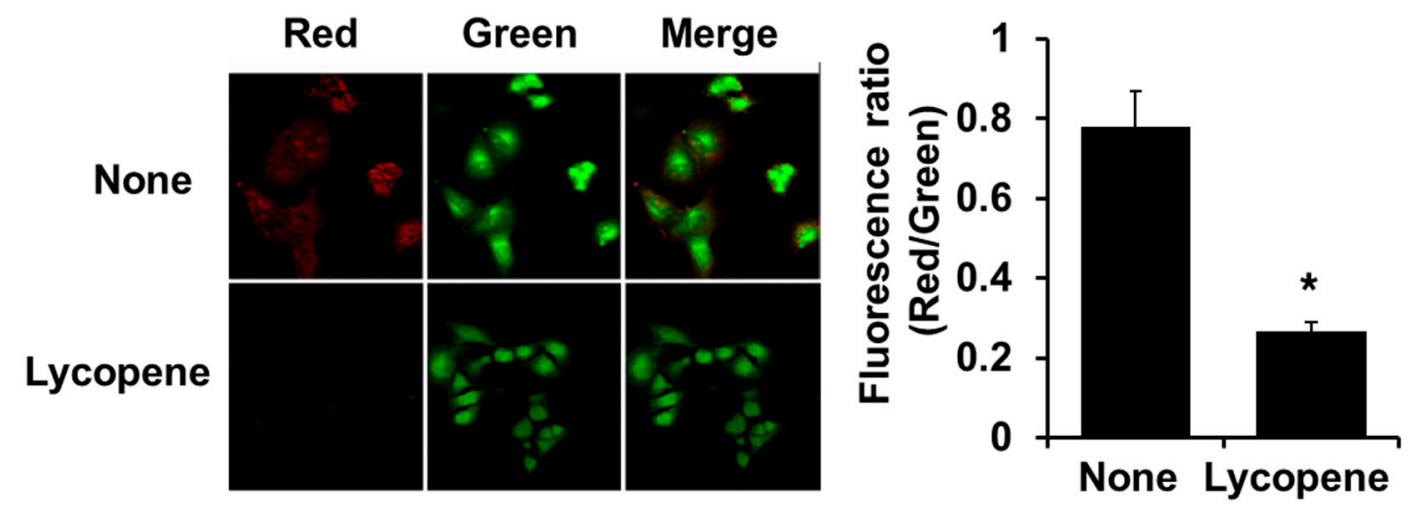

Figure 3. Lycopene decreased MMP in PANC-1 cells. Cells were treated with $0.5 \mu \mathrm{M}$ for $24 \mathrm{~h}$. The loss of MMP was examined using JC-1 staining. (A) Representative pictures are shown. JC-1 fluorescent dyes can gather in the matrix of mitochondria and produce red fluorescence. As the MMP decreased, JC-1 cannot gather the matrix and thus, JC-1 exists in the matrix as monomer, generating green fluorescence. (B) The ratio of the red and green fluorescence density is shown. Data are the mean \pm S.E. of four different experiments. * $p<0.05$ vs. the "None". "None" corresponds to the untreated cells; "Lycopene" corresponds to the cells treated with $0.5 \mu \mathrm{M}$ lycopene.

\subsection{Lycopene Suppresses NF-kB Activation in PANC-1 Cells}

In its resting state, NF- $\kappa B$ is bound with the inhibitor $\mathrm{I} \kappa \mathrm{B} \alpha$. Upon exposure to various stimuli, NF- $\kappa B$ activation occurs to release I $\mathrm{K} B$, which is then phosphorylated by IKK for proteasomal degradation. In addition, NF- $\mathrm{KB}$ is translocated to the nucleus where it transcribes target genes such as CIAP1, cIAP2, and survivin. In this study, we showed that DNA-binding activities of NF- $\mathrm{BB}$ are significantly reduced in lycopene-treated cells (Figure 4A). The inhibition of NF-kB by lycopene was confirmed using western blot analysis to assess the phosphorylation of $\operatorname{I} \mathrm{B} \alpha$. Lycopene inhibited phosphorylation of $I \kappa B \alpha$, indicating that it suppresses activation of NF- $\kappa B$ in PANC-1 cells (Figure 4B). 
A

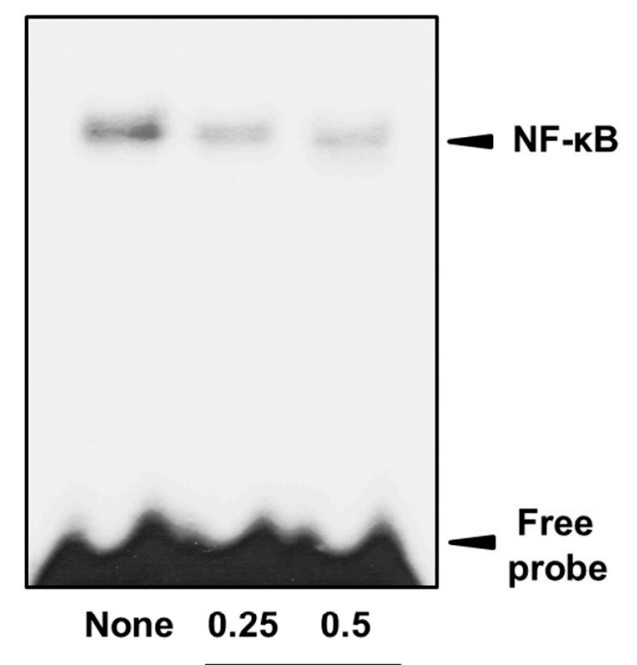

Lycopene $(\mu \mathrm{M})$

B
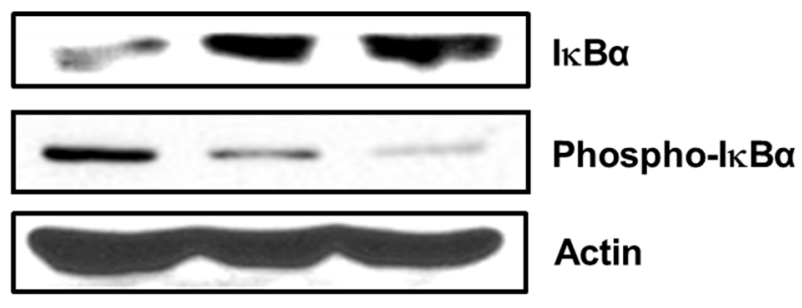

None $\quad 0.25 \quad 0.5$

Lycopene $(\mu \mathrm{M})$

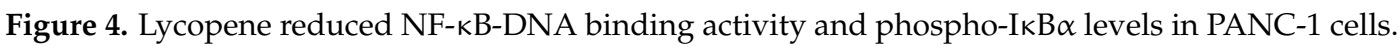
Cells were treated with the indicated concentrations of lycopene for $24 \mathrm{~h}$. (A) DNA-binding activity of NF- $\mathrm{B}$ B in nuclear extracts was examined by using electrophoretic mobility shift assay (EMSA). "None" corresponds to the untreated cells; " 0.25 " and " 0.5 " correspond to the cells treated with 0.25 and $0.5 \mu \mathrm{M}$ lycopene, respectively. (B) Western blot analysis was performed for the levels of phospho-IкB $\alpha$ and $\mathrm{I} \kappa \mathrm{B} \alpha$ (and the protein standard actin). Designations of the columns are the same as in (A).

\subsection{Lycopene Decreases Expression of cIAP1, cIAP2, and Survivin in PANC-1 Cells}

To examine the effect of lycopene on expression of cIAP1, cIAP2 and survivin, PANC-1 cells were treated with lycopene after which the respective levels of mRNA and protein were determined. Cells treated with lycopene contained decreased levels of the transcribed mRNAs as well as the translated proteins (Figure 5A,B). These results demonstrate that lycopene induces apoptosis of PANC-1 cells by suppressing expression of cIAP1, cIAP2, and survivin, which are mediated by activation of NF-kB. 


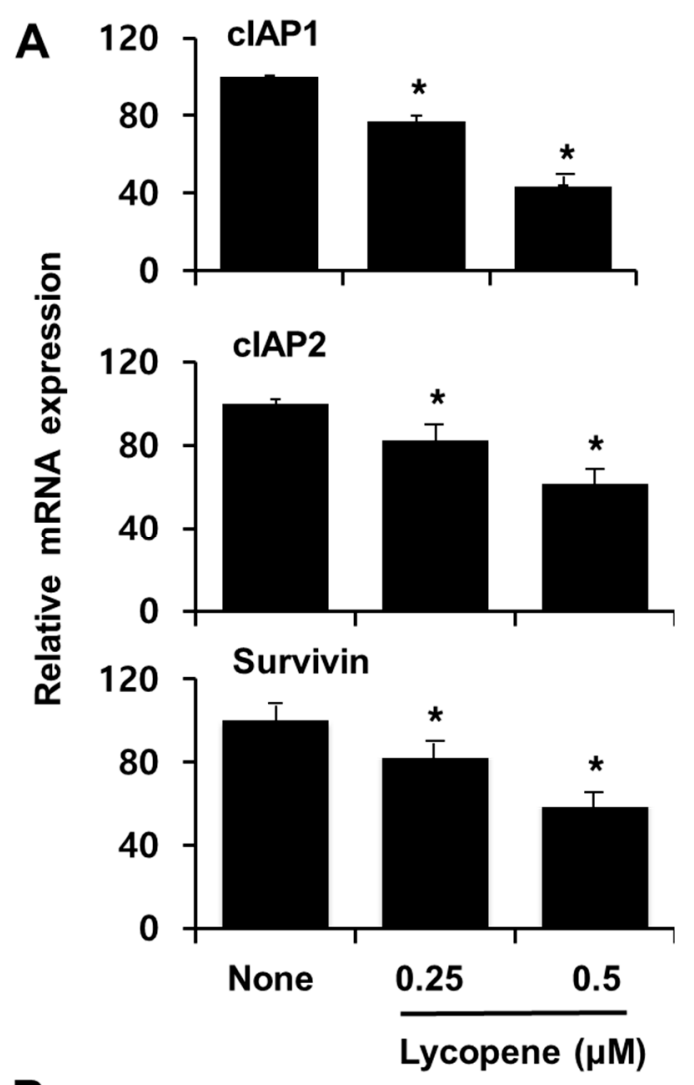

B

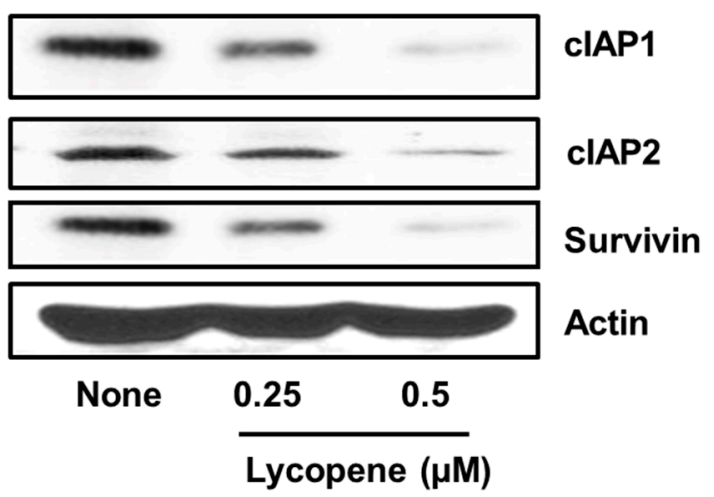

Figure 5. Lycopene decreased expression of cIAP1, cIAP2 and survivin in PANC-1 cells. Cells were treated with the indicated concentrations of lycopene for $24 \mathrm{~h}$ for mRNA and protein levels of cIAP1, cIAP2, and survivin. (A) mRNA levels of cIAP1, cIAP2, and survivin were determined by real-time polymerase chain reaction (PCR) analysis. ${ }^{*} p<0.05$ vs. None. "None" corresponds to untreated cells, " 0.25 " and " 0.5 " to the cells treated with 0.25 and $0.5 \mu \mathrm{M}$ lycopene, respectively. (B) Western blot analysis was performed for protein levels of cIAP1, cIAP2 and survivin (and the protein standard actin). Designations of the columns are the same as in (A).

\section{Discussion}

In the present study, we found that lycopene induced apoptosis of pancreatic cancer PANC-1 cells by decreasing intracellular and mitochondrial ROS levels, and consequently inhibiting NF- $\mathrm{KB}$ activation and expression of NF-kB target genes such as cIAP1, cIAP2, and survivin. Lycopene also inhibited mitochondrial function, as indicated by decreases in MMP and basal OCR) in PANC-1 cells Because the NF-KB target genes (cIAP1, cIAP2 and survivin) suppress caspase- 3 activation, indirect inhibition of NF- $\mathrm{kB}$ target gene expression by lycopene promotes caspase-3 activation. Thus, 
lycopene induces caspase-3-dependent apoptosis and increased the Bax to Bcl-2 ratio in PANC-1 cells. The present finding is summarized in Figure 6.

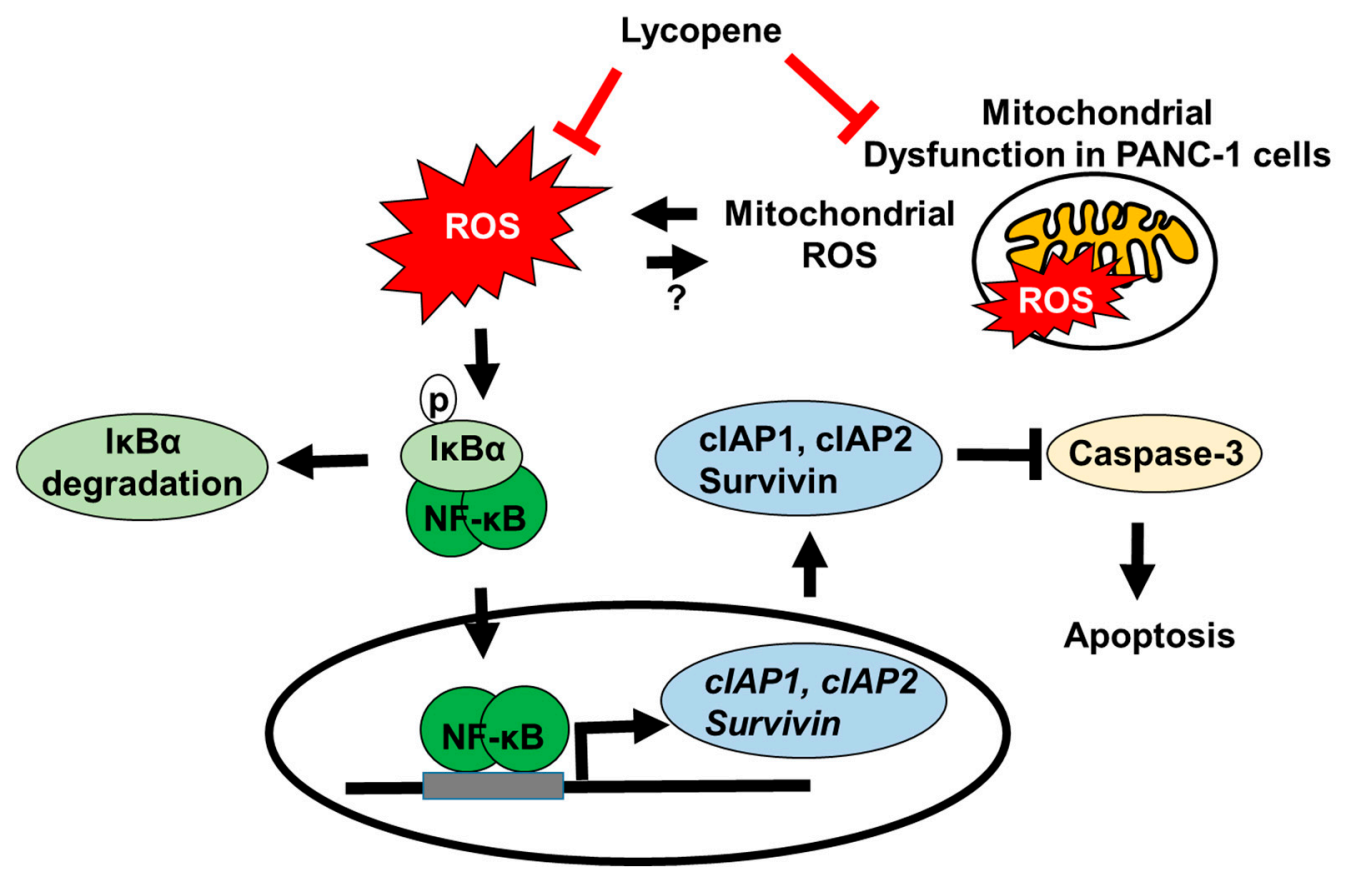

Figure 6. Schematic pathways for the inhibitory effect of lycopene on ROS-mediated NF- $\mathrm{kB}$ signaling and NF- $\mathrm{kB}$ target gene expression in PANC-1 cells.

ROS have been reported to be elevated in almost all cancers, and they appear to enhance cell survival and proliferation by stimulating carcinogenesis-related signaling pathways [46,47]. This is especially true in the development of pancreatic cancer where ROS serve as pro-survival and anti-apoptotic factors. An excess of ROS has been shown to have anti-apoptotic effects through activation of cancer-associated signaling pathways such as p38 mitogen activated protein kinases (MAPK), NF-KB and janus kinase/signal transducer and activator of transcription (JAK/STAT) [48-53]. These studies demonstrate that reducing ROS may induce the death of pancreatic cancer cells. It was supported by the present finding showing that decrease of ROS levels, by lycopene treatment, inhibited NF-KB-dependent expression of cell survival genes and thus, induced apoptosis in PANC-1 cells.

Regarding the effect of lycopene on mitochondrial function, Sandhir et al. [54] showed that 5-day administration of lycopene $(10 \mathrm{mg} / \mathrm{kg}$, orally) inhibited the activities of mitochondrial Complexes-II, IV and $\mathrm{V}$ along with reduction of mitochondrial respiration in striatum of 3-nitropropionic acid (3-NP)-treated rats. 3-NP caused neurobehavioral deficits with increased mitochondrial ROS and activated caspase-3 activity, which was suppressed by the administration of lycopene. Hantz et al. [55] showed that high concentrations of lycopene reduced mitochondrial membrane potential, an index of mitochondrial function, in prostate cancer cells. Therefore, mitochondria may be one of the target organs by lycopene treatment in some pathologic conditions including cancer. In the present study, lycopene decreased MMP, OCR, and mitochondrial ROS in PANC-1 cells, which supports the previous studies.

Fulda et al. [56] suggested that MMP decline can improve the efficiency of the cancer treatment. When the cells are disrupted by apoptosis-inducing stimuli, MMP changes occurs as the first event $[57,58]$. Therefore, maintaining MMP could prevent cancer cells from apoptosis [59]. In the present study, lycopene induced MMP decline, determined by color change from red to green. Untreated cells showed JC-1 aggregates (red) and monomers (green) while lycopene-treated cells have higher JC-1 monomers (green) than untreated cells. In PANC-1 cells, HT1080 human fibrosarcoma cells, and HepG2 hepatocellular carcinoma cells, JC-1 was distributed as aggregates (red) and monomers 
(green) without any treatment [60-62]. When MMP decreased by treatments, JC-1 monomers (green) increased and JC-1 aggregates (red) decreased. In the present study, Panc-1 cells showed both red and green fluorescence without lycopene treatment. Color was changed from red to green with lycopene treatment. Therefore, the fluorescence intensity ratio of red to green may be a more important indicator than red or green color intensity itself to determine MMP function.

In response to persistently high levels of ROS, the redox-sensitive transcription factor NF- $\mathrm{kB}$ is activated [63]. Constitutively activated NF- $\mathrm{kB}$ and elevated levels of ROS have been reported to make pancreatic cancer cells resistant to chemotherapy [64]. NF-KB exerts anti-apoptotic effects by inducing expression of IAPs [65]. IAPs are a group of anti-apoptotic factors that interact with each other by forming complexes which results in the suppression of protein or cooperative synergistic activities that protect cells from apoptosis [66-68]. IAPs are the only known endogenous proteins that suppress the activity of both initiator and effector caspases [69]. Among the IAP proteins, cIAP1, cIAP2 and survivin are known to be prominent members that exert anti-apoptotic effects by interfering with caspase-3, -7 and -9 [70,71]. Survivin reduces the auto-ubiquitination of IAPs, resulting in stabilization of IAPs and allowing interaction with caspase [72,73]. cIAP1 and cIAP2 are known to prevent downstream proteolytic processing of pro-caspase- $3,-6$ and -7 by blocking cytochrome c-induced activation of pro-caspase-9 in the intrinsic pathway [74]. Indeed, knockdown of cIAP1 and cIAP2 makes prostate cancer cells more sensitive to apoptosis [75] and knockdown of survivin inhibits cell growth in colorectal cancer and lung cancer cell lines [76]. These studies demonstrate that NF-kB-dependent genes play a critical role in inducing apoptosis by regulating caspases. The present study showed that lycopene suppressed NF- $\mathrm{kB}$ activation and expression of cIAP1, cIAP2 and survivin which was in parallel with a decrease in caspase-3 activation in PANC-1 cells. Lycopene also inhibits mitochondrial function, as indicated by decreases in OCR, and mitochondrial ROS in PANC-1 cells. Thus, lycopene-induced apoptosis appears to be associated with the reduction of intracellular and mitochondrial ROS and suppression of NF- $\mathrm{kB}$ signaling in pancreatic cancer cells.

Epidemiologic studies suggest that high consumption of fruits and vegetables, which are major sources of carotenoids, may play a role in the prevention of pancreatic cancer [77,78]. Drai et al. [79] showed that low concentrations of lycopene were shown in pancreatic cancer patients compared to normal health subjects. Abiaka et al. [80] demonstrated that low levels of lycopene and beta-carotene are strongly associated with a high risk of pancreatic cancer in Kuwait. A meta-analysis based publication from 1990 to 2013 showed that lycopene intake was inversely associated with pancreatic cancer risk, while alpha-carotene and cryptoxanthin intake had no significant relationship with pancreatic cancer risk [81]. They also reported that when stratified by ethnicity, there was an inverse relationship between lycopene intake and pancreatic cancer risk in Caucasians, while this correlation was not shown in the mixed population.

Kavanaugh et al. [82] described a U.S. Food and Drug Administration (FDA) review of tomato and/or lycopene intake with respect to risk reduction for certain cancers. The FDA found no evidence to support an association between lycopene intake and a reduced risk of pancreatic cancer. Nkondjock et al. [83] investigated the association between dietary carotenoids and pancreatic cancer risk using 462 pancreatic cancer cases and 4721 population-based controls in 8 Canadian provinces. They suggested that a diet rich in tomatoes and tomato-based products with high lycopene content may help reduce pancreatic cancer risk. Therefore, we have no concrete evidence between dietary intake of lycopene and reduction of pancreatic cancer incidence based on epidemiological studies. Since various factors, such as dietary factors, physical activity, smoking, genetic variations, ethnics, etc., are involved in epidemiologic studies, it may be difficult to show the direct relation of low lycopene intake and pancreatic cancer development.

The limitation of the present study is that we used one cell line (PANC-1 cells) for lycopene effect on expression of NF-kB-dependent survival genes and cancer cell survival. For a further study, more pancreatic cancer cell lines should be used to assess the anti-cancer effect of lycopene. More importantly, this should determine glucose consumption of the cells and medium content of lactate before and 
after lycopene treatment. This study may explain whether lycopene-induced decrease in OCR is a consequence of compensation by increase in anaerobic pathway or not.

Here, we found that lycopene inhibits oxidative stress and ROS-mediated NF- $k B$ signaling pathway in pancreatic cancer cells. Since NF- $\kappa B$ target genes are survival genes (cIAP1, cIAP2 and survivin) which suppress caspase- 3 activation, lycopene induces caspase- 3 - dependent apoptosis by suppressing survival genes in PANC-1 cells. Even though there is no concrete evidence of a link between dietary intake of lycopene and low risk of pancreatic cancer, we suggest that consumption of lycopene-containing foods or supplementation of lycopene may decrease risk of pancreatic cancer based on the present finding.

Author Contributions: Y.J. performed the research and wrote the paper. J.W.L. contributed new reagents and analytical tools. H.K. designed the research, analyzed the data, and edited the paper. All authors approved the manuscript in its current form.

Acknowledgments: This study was supported by a Brain Korea 21 PLUS Project, College of Human Ecology, Yonsei University, Seoul 03722, Republic of Korea. Part of this manuscript is presented at Experimental Biology 2016, San Diego, CA, USA (2-6 April 2016). The abstract of the presentation was published in the FASEB Journal 30(1), Supp. 691.23, 2016.

Conflicts of Interest: The authors declare no conflict of interest.

\section{References}

1. Li, D.; Xie, K.; Wolff, R.; Abbruzzese, J.L. Pancreatic cancer. Lancet 2004, 363, 1049-1057. [CrossRef]

2. Maitra, A.; Hruban, R.H. Pancreatic cancer. Annu. Rev. Pathol. 2008, 3, 157-188. [CrossRef]

3. Ilic, M.; Ilic, I. Epidemiology of pancreatic cancer. World J. Gastroenterol. 2016, 22, 9694-9705. [CrossRef] [PubMed]

4. Jung, K.W.; Won, Y.J.; Kong, H.J.; Lee, E.S.; Community of Population-Based Regional Cancer Registries. Cancer statistics in Korea: Incidence, mortality, survival, and prevalence in 2015. Cancer Res. Treat. 2018, 50, 303-316. [CrossRef]

5. Fulda, S. Apoptosis pathways and their therapeutic exploitation in pancreatic cancer. J. Cell Mol. Med. 2009, 13, 1221-1227. [CrossRef] [PubMed]

6. Komori, S.; Osada, S.; Yoshida, K. Novel strategy with gemcitabine for advanced pancreatic cancer. ISRN Oncol. 2011, 2011, 936893. [CrossRef] [PubMed]

7. Wang, W.B.; Yang, Y.; Zhao, Y.P.; Zhang, T.P.; Liao, Q.; Shu, H. Recent studies of 5-fluorouracil resistance in pancreatic cancer. World J. Gastroenterol. 2014, 20, 15682-15690. [CrossRef]

8. Noble, S.; Goa, K.L. Gemcitabine. A review of its pharmacology and clinical potential in non-small cell lung cancer and pancreatic cancer. Drugs 1997, 54, 447-472. [CrossRef]

9. Lee, K.H. Chemotherapy and targeted therapy with management of related complications in pancreatic cancer. Korean J. Pancreas Biliary Tract 2015, 20, 5-13. [CrossRef]

10. Yokoyama, C.; Sueyoshi, Y.; Ema, M.; Mori, Y.; Takaishi, K.; Hisatomi, H. Induction of oxidative stress by anticancer drugs in the presence and absence of cells. Oncol. Lett. 2017, 14, 6066-6070. [CrossRef]

11. Conklin, K.A. Dietary antioxidants during cancer chemotherapy: impact on chemotherapeutic effectiveness and development of side effects. Nutr. Cancer. 2000, 37, 1-18. [CrossRef] [PubMed]

12. Ju, H.Q.; Gocho, T.; Aguilar, M.; Wu, M.; Zhuang, Z.N.; Fu, J.; Yanaga, K.; Huang, P.; Chiao, P.J. Mechanisms of overcoming intrinsic resistance to gemcitabine in pancreatic ductal adenocarcinoma through the redox modulation. Mol. Cancer Ther. 2015, 14, 789-798. [CrossRef]

13. Yasued, A.; Urushima, H.; Ito, T. Efficacy and interaction of antioxidant supplements as adjuvant therapy in cancer treatment: A systematic review. Integr. Cancer Ther. 2016, 15, 17-39. [CrossRef]

14. Fu, Y.; Yang, G.; Zhu, F.; Peng, C.; Li, W.; Li, H.; Kim, H.G.; Bode, A.M.; Dong, Z.; Dong, Z. Antioxidants decrease the apoptotic effect of 5-Fu in colon cancer by regulating Src-dependent caspase-7 phosphorylation. Cell Death Dis. 2014, 5, e983. [CrossRef] [PubMed]

15. Nogueira, V.; Hay, N. Molecular pathways: Reactive oxygen species homeostasis in cancer cells and implications for cancer therapy. Clin. Cancer Res. 2013, 19, 4309-4314. [CrossRef]

16. Durackova, Z. Some current insights into oxidative stress. Physiol. Res. 2010, 59, 459-469. 
17. Schraufstatter, I.; Hyslop, P.A.; Jackson, J.H.; Cochrane, C.G. Oxidant-induced DNA damage of target cells. J. Clin. Investig. 1988, 82, 1040-1050. [CrossRef]

18. Poyton, R.O.; Ball, K.A.; Castello, P.R. Mitochondrial generation of free radicals and hypoxic signaling. Trends Endocrinol. Metab. 2009, 20, 332-340. [CrossRef]

19. Epstein, T.; Gatenby, R.A.; Brown, J.S. The Warburg effect as an adaptation of cancer cells to rapid fluctuations in energy. PLoS ONE 2017, 12, e0185085. [CrossRef]

20. Wu, W.; Zhao, S. Metabolic changes in cancer: Beyond the Warburg effect. Acta Biochim. Biophys. Sin. (Shanghai) 2013, 45, 18-26. [CrossRef]

21. Vander Heiden, M.G.; Cantley, L.C.; Thompson, C.B. Understanding the Warburg effect: The metabolic requirements of cell proliferation. Science 2009, 324, 1029-1033. [CrossRef]

22. Guda, M.R.; Asuthkar, S.; Labak, C.M.; Tsung, A.J.; Alexandrov, I.; Mackenzie, M.J.; Prasad, D.V.; Velpula, K.K. Targeting PDK4 inhibits breast cancer metabolism. Am. J. Cancer Res. 2018, 8, 1725-1738. [PubMed]

23. Bauer, G. Tumor cell-protective catalase as a novel target for rational therapeutic approaches based on specific intercellular ROS signaling. Anticancer Res. 2012, 32, 2599-2624.

24. Ishikawa, K.; Takenaga, K.; Akimoto, M.; Koshikawa, N.; Yamaguchi, A.; Imanishi, H.; Nakada, K.; Honma, Y.; Hayashi, J. ROS-generating mitochondrial DNA mutations can regulate tumor cell metastasis. Science 2008, 320, 661-664. [CrossRef] [PubMed]

25. Afanas'ev, I. Reactive oxygen species signaling in cancer: Comparison with aging. Aging Dis. 2014, 2, $219-230$.

26. Li, N.; Michael, K. Is NF-kB the sensor of oxidative stress? FASEB J. 1999, 13, 1137-1143. [CrossRef]

27. Grivennikov, S.I.; Karin, M. Dangerous liaisons: STAT3 and NF- $\mathrm{kB}$ collaboration and crosstalk in cancer. Cytokine Growth Factor Rev. 2010, 21, 11-19. [CrossRef]

28. Karin, M.; Cao, Y.; Greten, F.R.; Li, Z.W. NF-кB in cancer: From innocent bystander to major culprit. Nat. Rev. Cancer 2002, 2, 301-310. [CrossRef] [PubMed]

29. Moon, D.O.; Kim, M.O.; Kang, S.H.; Choi, Y.H.; Kim, G.Y. Sulforaphane suppresses TNF- $\alpha$-mediated activation of NF- $\mathrm{kB}$ and induces apoptosis through activation of reactive oxygen species-dependent caspase-3. Cancer Lett. 2009, 274, 132-142. [CrossRef]

30. Wang, C.Y.; Mayo, M.W.; Korneluk, R.G.; Goeddel, D.V.; Baldwin, A.S. NF-кB antiapoptosis: Induction of TRAF1 and TRAF2 and c-IAP1 and c-IAP2 to suppress caspase-8 activation. Science 1998, 281, 1680-1683. [CrossRef] [PubMed]

31. Dai, Y.; Theodore, T.S.; Xu, L. Overcoming cancer therapy resistance by targeting inhibitors of apoptosis proteins and nuclear factor-kappa B. Am. J. Transl. Res. 2009, 1, 1.

32. Vucic, D.; Fairbrother, W.J. The inhibitor of apoptosis proteins as therapeutic targets in cancer. Clin. Cancer Res. 2007, 13, 5995-6000. [CrossRef]

33. Lopes, R.B.; Gangeswaran, R.; McNeish, I.A.; Wang, Y.; Lemoine, N.R. Expression of the IAP protein family is dysregulated in pancreatic cancer cells and is important for resistance to chemotherapy. Int. J. Cancer 2007, 120, 2344-2352. [CrossRef] [PubMed]

34. Arlt, A.; Müerköster, S.S.; Schäfer, H. Targeting apoptosis pathways in pancreatic cancer. Cancer Lett. 2013, 332, 346-358. [CrossRef]

35. Salman, H.; Bergman, M.; Djaldetti, M.; Bessler, H. Lycopene affects proliferation and apoptosis of four malignant cell lines. Biomed. Pharmacother. 2007, 61, 366-369. [CrossRef] [PubMed]

36. Teodoro, A.J.; Oliveira, F.L.; Martins, N.B.; Maia Gde, A.; Martucci, R.B.; Borojevic, R. Effect of lycopene on cell viability and cell cycle progression in human cancer cell lines. Cancer Cell Int. 2012, 12, 36. [CrossRef] [PubMed]

37. Venkateswaran, V.; Venier, N.A.; Colquhoun, A.J.; Fleshner, N.E.; Klotz, L.H. Lycopene enhances the anti-proliferative and pro-apoptotic effects of capsaicin in prostate cancer in vitro. J. Cancer Res. 2012, 1, 30.

38. Nitsche, C.; Simon, P.; Weiss, F.U.; Fluhr, G.; Weber, E.; Gärtner, S.; Behn, C.O.; Kraft, M.; Ringel, J.; Aghdassi, A.; et al. Environmental risk factors for chronic pancreatitis and pancreatic cancer. Dig. Dis. 2011, 29, 235-242. [CrossRef]

39. Chen, J.; Jiang, W.; Shao, L.; Zhong, D.; Wu, Y.; Cai, J. Association between intake of antioxidants and pancreatic cancer risk: a meta-analysis. Int. J. Food Sci. Nutr. 2016, 67, 744-753. [CrossRef] [PubMed]

40. Burney, P.G.; Comstock, G.W.; Morris, J.S. Serologic precursors of cancer: Serum micronutrients and the subsequent risk of pancreatic cancer. Am. J. Clin. Nutr. 1989, 49, 895-900. [CrossRef] 
41. Han, X.; Li, J.; Brasky, T.M.; Xun, P.; Stevens, J.; White, E.; Gammon, M.D.; He, K. Antioxidant intake and pancreatic cancer risk: The Vitamins and Lifestyle (VITAL) Study. Cancer 2013, 119, 1314-1320. [CrossRef] [PubMed]

42. Zhang, J.; Zhang, X.; Dhakal, I.B.; Gross, M.D.; Kadlubar, F.F.; Anderson, K.E. Sequence variants in antioxidant defense and DNA repair genes, dietary antioxidants, and pancreatic cancer risk. Int. J. Mol. Epidemiol. Genet. 2011, 2, 236-244.

43. Palozza, P.; Parrone, N.; Simone, R.; Catalano, A. Role of lycopene in the control of ROS-mediated cell growth: Implications in cancer prevention. Curr. Med. Chem. 2011, 18, 1846-1860. [CrossRef] [PubMed]

44. Palozza, P.; Simone, R.; Catalano, A.; Monego, G.; Barini, A.; Mele, M.C.; Parrone, N.; Trombino, S.; Picci, N.; Ranelletti, F.O. Lycopene prevention of oxysterol-induced proinflammatory cytokine cascade in human macrophages: inhibition of NF- $\mathrm{B}$ nuclear binding and increase in PPAR $\gamma$ expression. J. Nutr. Biochem. 2011, 22, 259-268. [CrossRef]

45. Huang, C.S.; Fan, Y.E.; Lin, C.Y.; Hu, M.L. Lycopene inhibits matrix metalloproteinase-9 expression and down-regulates the binding activity of nuclear factor-kappa B and stimulatory protein-1. J. Nutr. Biochem. 2007, 18, 449-456. [CrossRef]

46. Liou, G.Y.; Storz, P. Reactive oxygen species in cancer. Free Radic. Res. 2010, 44, 479-496. [CrossRef] [PubMed]

47. Storz, P. Reactive oxygen species in tumor progression. Front. Biosci. 2005, 10, 1881-1896. [CrossRef]

48. Green, D.R. Death and NF-kappaB in T cell activation: Life at the edge. Mol. Cell 2003, 11, 551-552. [CrossRef]

49. Lee, J.K.; Edderkaoui, M.; Truong, P.; Ohn, I.; Jang, K.T. NADPH oxidase promotes pancreatic cancer cell survival via inhibiting JAK2 dephosphorylation by tyrosine phosphatases. Gastroenterology 2007, 133, 1637-1648. [CrossRef]

50. Fukuda, A.; Wang, S.C.; Morris, J.P., 4th; Folias, A.E.; Liou, A.; Kim, G.E.; Akira, S.; Boucher, K.M.; Firpo, M.A.; Mulvihill, S.J.; et al. Stat3 and MMP7 contribute to pancreatic ductal adenocarcinoma initiation and progression. Cancer Cell 2011, 19, 441-455. [CrossRef]

51. Lesina, M.; Kurkowski, M.U.; Ludes, K.; Rose-John, S.; Treiber, M.; Klöppel, G.; Yoshimura, A.; Reindl, W.; Sipos, B.; Akira, S.; et al. Stat3/Socs3 activation by IL-6 transsignaling promotes progression of pancreatic intraepithelial neoplasia and development of pancreatic cancer. Cancer Cell 2011, 19, 456-469. [CrossRef] [PubMed]

52. Ju, K.D.; Lim, J.W.; Kim, K.H.; Kim, H. Potential role of NADPH oxidase-mediated activation of Jak2/Stat3 and mitogen-activated protein kinases and expression of TGF- $\beta 1$ in the pathophysiology of acute pancreatitis. Inflamm. Res. 2011, 60, 791-800. [CrossRef] [PubMed]

53. Vaquero, E.C.; Edderkaoui, M.; Pandol, S.J.; Gukovsky, I.; Gukovskaya, A.S. Reactive oxygen species produced by NAD(P)H oxidase inhibit apoptosis in pancreatic cancer cell. J. Biol. Chem. 2004, 279, 34643-34654. [CrossRef] [PubMed]

54. Sandhir, R.; Mehrotra, A.; Kamboj, S.S. Lycopene prevents 3-nitropropionic acid-induced mitochondrial oxidative stress and dysfunctions in nervous system. Neurochem. Int. 2010, 57, 579-587. [CrossRef]

55. Hantz, H.L.; Young, L.F.; Martin, K.R. Physiologically attainable concentrations of lycopene induce mitochondrial apoptosis in LNCaP human prostate cancer cells. Exp. Biol. Med. (Maywood) 2005, 230, 171-179. [CrossRef] [PubMed]

56. Fulda, S.; Galluzzi, L.; Kroemer, G. Targeting mitochondria for cancer therapy. Nat. Rev. Drug Discov. 2010, 9, 447-464. [CrossRef] [PubMed]

57. Leber, B.; Lin, J.; Andrews, D.W. Still embedded together binding to membranes regulates Bcl-2 protein interactions. Oncogene 2010, 29, 5221-5230. [CrossRef]

58. Yang, C.L.; Ma, Y.G.; Xue, Y.X.; Liu, Y.Y.; Xie, H.; Qiu, G.R. Curcumin induces small cell lung cancer NCI-H446 cell apoptosis via the reactive oxygen species-mediated mitochondrial pathway and not the cell death receptor pathway. DNA Cell Biol. 2012, 31, 139-150. [CrossRef] [PubMed]

59. Ly, J.D.; Grubb, D.R.; Lawen, A. The mitochondrial membrane potential (deltapsi(m)) in apoptosis: An update. Apoptosis 2003, 8, 115-128. [CrossRef]

60. Liu, J.X.; Zhang, J.H.; Li, H.H.; Lai, F.J.; Chen, K.J.; Chen, H.; Luo, J.; Guo, H.C.; Wang, Z.H.; Lin, S.Z. Emodin induces Panc-1 cell apoptosis via declining the mitochondrial membrane potential. Oncol. Rep. 2012, 28, 1991-1996. [CrossRef] 
61. Kim, A.; Im, M.; Hwang, Y.H.; Yang, H.J.; Ma, J.Y. Jaeumganghwa-Tang induces apoptosis via the mitochondrial pathway and Lactobacillus fermentation enhances its anti-cancer activity in HT1080 human fibrosarcoma cells. PLoS ONE 2015, 10, e0127898. [CrossRef]

62. Sakamuru, S.; Li, X.; Matias, S.; Attene-Ramos, M.S.; Huang, R.; Lu, J.; Shou, L.; Shen, M.; Tice, R.R.; Austin, C.P.; et al. Application of a homogenous membrane potential assay to assess mitochondrial function. Physiol. Genom. 2012, 44, 495-503. [CrossRef] [PubMed]

63. Wang, Q.; Wang, X.B.; Evers, B.M. Induction of cIAP-2 in human colon cancer cells through PKC $\delta / N F-\kappa B$. J. Biol. Chem. 2003, 278, 51091-51099. [CrossRef] [PubMed]

64. Wang, C.Y.; Cusack, J.C.; Liu, R.; Baldwin, A.S. Control of inducible chemoresistance: Enhanced anti-tumor therapy through increased apoptosis by inhibition of NF-кB. Nat. Med. 1999, 5, 412-417. [CrossRef]

65. Liu, Z.G.; Hsu, H.; Goeddel, D.V.; Karin, M. Dissection of TNF receptor 1 effector functions: JNK activation is not linked to apoptosis while NF- $\mathrm{kB}$ activation prevents cell death. Cell 1996, 87, 565-576. [CrossRef]

66. Dohi, T.; Okada, K.; Xia, F.; Wilford, C.E.; Samuel, T.; Welsh, K.; Marusawa, H.; Zou, H.; Armstrong, R.; Matsuzawa, S.; et al. An IAP-IAP complex inhibits apoptosis. J. Biol. Chem. 2004, 279, 34087-34090. [CrossRef] [PubMed]

67. Cheung, H.H.; Plenchette, S.; Kern, C.J.; Mahoney, D.J.; Korneluk, R.G. The RING domain of cIAP1 mediates the degradation of RING-bearing inhibitor of apoptosis proteins by distinct pathways. Mol. Biol. Cell 2008, 19, 2729-2740. [CrossRef]

68. Conze, D.B.; Albert, L.; Ferrick, D.A.; Goeddel, D.V.; Yeh, W.C.; Mak, T.; Ashwell, J.D. Posttranscriptional downregulation of c-IAP2 by the ubiquitin protein ligase c-IAP1 in vivo. Mol. Cell Biol. 2005, 25, 3348-3356. [CrossRef]

69. LaCasse, E.C.; Baird, S.; Korneluk, R.G.; MacKenzie, A.E. The inhibitors of apoptosis (IAPs) and their emerging role in cancer. Oncogene 1998, 17, 3247-3259. [CrossRef]

70. Roy, N.; Deveraux, Q.L.; Takahashi, R.; Salvesen, G.S.; Reed, J.C. The c-IAP-1 and c-IAP-2 proteins are direct inhibitors of specific caspases. EMBO J. 1997, 16, 6914-6925. [CrossRef] [PubMed]

71. Yang, Y.L.; Li, M. The IAP family: endogenous caspase inhibitors with multiple biological activities. Cell Res. 2000, 10, 169-177. [CrossRef] [PubMed]

72. Dubrez-Daloz, L.; Dupoux, A.; Cartier, J. IAPs: More than just inhibitors of apoptosis proteins. Cell Cycle 2008, 7, 1036-1046. [CrossRef]

73. Eckelman, B.P.; Salvesen, G.S.; Scott, F.L. Human inhibitor of apoptosis proteins: Why XIAP is the black sheep of the family. EMBO Rep. 2006, 7, 988-994. [CrossRef]

74. Deveraux, Q.L.; Roy, N.; Stennicke, H.R.; Van Arsdale, T.; Zhou, Q.; Srinivasula, S.M.; Alnemri, E.S.; Salvesen, G.S.; Reed, J.C. IAPs block apoptotic events induced by caspase-8 and cytochrome c by direct inhibition of distinct caspases. EMBO J. 1998, 17, 2215-2223. [CrossRef] [PubMed]

75. Gill, C.; Dowling, C.; O'Neill, A.J.; Watson, R.W.G. Effects of cIAP-1, cIAP-2 and XIAP triple knockdown on prostate cancer cell susceptibility to apoptosis cell survival and proliferation. Mol. Cancer 2009, 8, 1. [CrossRef] [PubMed]

76. Wang, R.; Lin, F.; Wang, X.; Gao, P.; Dong, K.; Zou, A.M.; Cheng, S.Y.; Wei, S.H.; Zhang, H.Z. Silencing the livin gene expression to inhibit proliferation and enhance chemosensitivity in tumor cells. Cancer Gene Ther. 2008, 15, 402-412. [CrossRef] [PubMed]

77. Khachik, F.; Carvalho, L.; Bernstein, P.S.; Muir, G.J.; Zhao, D.Y.; Katz, N.B. Chemistry, distribution, and metabolism of tomato carotenoids and their impact on human health. Exp. Biol. Med. (Maywood) 2002, 227, 845-851. [CrossRef] [PubMed]

78. Zhang, L.X.; Cooney, R.V.; Bertram, J.S. Carotenoids enhance gap junctional communication and inhibit lipid peroxidation in $\mathrm{C} 3 \mathrm{H} / 10 \mathrm{~T} 1 / 2$ cells: Relationship to their cancer chemopreventive action. Carcinogenesis 1991, 12, 2109-2114. [CrossRef]

79. Drai, J.; Borel, P.; Faure, H.; Galabert, C.; Le Moël, G.; Laromiguière, M.; Fayol, V. Fasting plasma carotenoids concentrations in Crohn's and pancreatic cancer patients compared to control subjects. Int. J. Vitam. Nutr. Res. 2009, 79, 87-94. [CrossRef]

80. Abiaka, C.D.; Al-Awadi, F.M.; Al-Sayer, H.; Gulshan, S.; Behbehani, A.; Farghaly, M. Plasma micronutrient antioxidant in cancer patients. Cancer Detect. Prev. 2001, 25, 245-253. 
81. Huang, X.; Gao, Y.; Zhi, X.; Ta, N.; Jiang, H.; Zheng, J. Association between vitamin A, retinol and carotenoid intake and pancreatic cancer risk: Evidence from epidemiologic studies. Sci. Rep. 2016, 6, 38936. [CrossRef] [PubMed]

82. Kavanaugh, C.J.; Trumbo, P.R.; Ellwood, K.C. The U.S. Food and Drug Administration's evidence-based review for qualified health claims: Tomatoes, lycopene, and cancer. Natl. Cancer Inst. 2007, 99, 1074-1085. [CrossRef] [PubMed]

83. Nkondjock, A.; Ghadirian, P.; Johnson, K.C.; Krewski, D. Canadian Cancer Registries Epidemiology Research Group. Dietary intake of lycopene is associated with reduced pancreatic cancer risk. J. Nutr. 2005, 135, 592-597. [PubMed]

(C) 2019 by the authors. Licensee MDPI, Basel, Switzerland. This article is an open access article distributed under the terms and conditions of the Creative Commons Attribution (CC BY) license (http:/ / creativecommons.org/licenses/by/4.0/). 